\title{
高層建築におけるループ通気方式排水立て管システムの 排水能力把握とその予測手法に関する研究
}

\section{STUDY ON THE UNDERSTANDING OF THE DRAINAGE PERFORMANCE OF THE LOOP VENT STACK SYSTEM FOR HIGH-RISE BUILDINGS AND A PREDICTION METHOD THEREOF}

\author{
大塚雅 之*1, 杉本遼太 ${ }^{* 2}$, 河野 慎*3, 小林直 史 $^{* 4}$ \\ Masayuki OTSUKA, Ryota SUGIMOTO, Shin KOUNO \\ and Naofumi KOBAYASHI
}

\begin{abstract}
Drainage performance values of loop vent stack systems refer to the values specified by SHASE-S 206-2009, but these values are not supported by any systematic experimental study. This study aims to identify, systematically, the drainage performance of the loop vent stack system for high-rise buildings by understanding in-pipe pressure variations and air flow characteristics thereof, and suggests new drainage performance values. The study further discusses a prediction method of drainage performance by using a series of models developed by the authors with the intention of identifying the effectiveness of the method on the loop vent stack system.
\end{abstract}

Keywords : Drainage performance, loop vent system, Drainage stack system, Prediction method 排水能力, ループ通気方式, 排水立て管システム, 予測手法,

\section{1. はじめに}

業務用建物では、集合住宅に比べ排水横枝管への衛生器具の設置 数も多く、それらの同時使用によって排水立て管への排水負荷も増 加するため、管内圧力変動を緩和し、トラップ封水を保護する目的 から排水立て管に通気立て管とループ通気管を併設したループ通気 方式の排水立て管システムが一般に用いられている。特にループ通 気方式は、伸頂通気方式に比べ排水配管と通気配管から成る複雑な 通気管路網を構成するため、トラップの破封の要因となる管内圧力 や通気流量について、実験的かつ理論的に解明し、それらの結果を もとに、設計に用いる排水立て管システムの排水能力（設計用許容 流量）注1)を適正に把握する必要がある。

しかし、既往研究において、わが国では石原 ${ }^{1)}$ が換気管路網を模 した排水・通気管路網モデル図を提案したが、それを解析するため の通気特性データの収集や排水能力の推定までには至らなかった。 その後は、幾つかの実証研究 2)3) が先行して実施され、現行の SHASES 206-2009（以下、SHASE- S 206）のループ通気方式の設計用許容流 量や必要通気流量が決定され、現在に至っている。しかし、それら
の数值が決定された当時には、現行の SHASE-S 218-2014（以下、SHASES 218）のような排水立て管システムの排水能力試験法も策定され ていなかったため、系統的な試験を実施した上で提案されたもので はない。一方、海外においては、米国の技術基準である National Plumbing Code（以下、NPC）において、主に各個通気方式の排水・ 通気管の設計法や複雑な配管方法が示されているが、実務的な内容 が主であり、設計用の数值等を決定に至った理論的な根拠が示され ていない4)。欧州ではCIB W062 シンポジウム等において、Swaffield らがループ通気管路内の通気流量や管内圧力変動の解析について一 連の研究を展開してきた ${ }^{5)}$ 。しかし、欧州の一連の研究成果につい ては、理論解析は実施されているが、排水能力や通気流量の解析結 果を設計実務へ反映させるまでに至っていない。筆者はこのような 国内外の課題点を指摘し、伸頂通気方式、通気弁通気方式、ループ 通気方式などの各種通気システムの排水能力や通気特性を実験的か つ理論的に解明寸るための研究を実施してきた ${ }^{6)}$ 。その研究の一環 として、既報 ${ }^{7)}$ ９）において、通気弁を伸頂通気管、排水横枝管に 設置した通気弁排水横枝管設置システムの管内圧力と通気流量に関

\footnotetext{
*1 関東学院大学建築 $\cdot$ 環境学部建築 $\cdot$ 環境学科 教授. 工博

*2 (株)日本設計 工修(元 関東学院大学工学研究科)

*3 高砂熱学工業株) 工修(元 関東学院大学工学研究科)

*4 (株)日立プラントサービス 工修 (元 関東学院大学工学研究科)
}

Prof., Dept. of Architecture and Environmental Design, College of Architecture and Environmental Design, Kanto Gakuin Univ., Dr.Eng.

NIHON SEKKEI, INC., M.Eng. (Former Graduate School of Engineering, Kanto Gakuin Univ.) Takasago Thermal Engineering Co., Ltd., M.Eng. (Former Graduate School of Engineering, Kanto Gakuin Univ.)

Hitachi Plant Services Co., Ltd., M.Eng. (Former Graduate School of Engineering, Kanto Gakuin Univ.) 
する実験と排水・通気管路網を用いた理論的な解析を実施しており、 その内容の一部は海外でも紹介されている ${ }^{10)}$ 。

このような背景より、本報はこの研究を発展させ、ループ通気方 式を中心に検討を行い、以下の 3 点を明らかにする。先ず、高層建 築のループ通気方式の排水立て管システムに、SHASE-S 218 に基づ く排水能力試験法により系統的に排水負荷を与えた際の管内圧力と 通気流量に関する特性を把握する。次に、その実験結果より得られ た排水能力を設計用許容流量と見なし、現行の SHASE-S 206 に規定 するループ通気方式の值と比較し、新たに設計に資するデータとし て提案する。最後に、理論的な根拠として、既報 ${ }^{7)}$ ９) の排水・通気 管路網モデルとその理論解析をさらに拡張させ、代表的なループ通 気方式の通気流量を求め、それから管内圧力、さらには排水能力の 推定へと予測手法を展開させ、同手法の適用の可能性を検討する。

\section{2. 実験概要}

実験は、以下の 2.1 と 2.2 について実施する。

\section{1 各種通気方式における排水能力把握実験}

実験は、関東学院大学敷地内にある地上 9 階建て（高さ約 25m) の高層建築環境設備シミュレーションタワー装置を用いて実施する。 Fig. 1 に、ループ通気管を全階の排水横枝管に設置した供試排水立 て管システムの例（後述の Table 1 (5) 全箇所設置方式）を示す。同 システムの管径は、排水立て管を $100 \mathrm{~A}$ 、排水横枝管を $75 \mathrm{~A}$ (こう配 1/100)、排水横主管を $125 \mathrm{~A}$ (こう配 1/150) とする。また、通気立て 管及びループ通気管の管径は同径の $75 \mathrm{~A}$ とし、排水横主管はストレ 一トに長さ約 $11 \mathrm{~m}$ 延長したもの（以下、ストレート）、排水立て管の 管芯より $1 \mathrm{~m} 、 3 \mathrm{~m}$ の位置にそれぞれ第 1 水平曲がりを設けたもの（以 下、 $1 \mathrm{~m}$ 曲がり、 $3 \mathrm{~m}$ 曲がり) とする。ただし、一部、実験条件に応じ て排水・通気管の管径を変更する。本報では、ループ通気管の効果 を系統的に捉えるため、Table 1(1)～(5) に示す 5 つの方式につい て、順に検討していく。同表には既往研究においても基準システム とした伸頂通気方式、それに通気立て管のみを併設した通気立て管 方式、中間階（6 階）の排水横枝管のみにループ通気管を設置した 1 籄所設置方式、 7 階と 5 階の 2 箇所の排水横枝管にループ通気管を
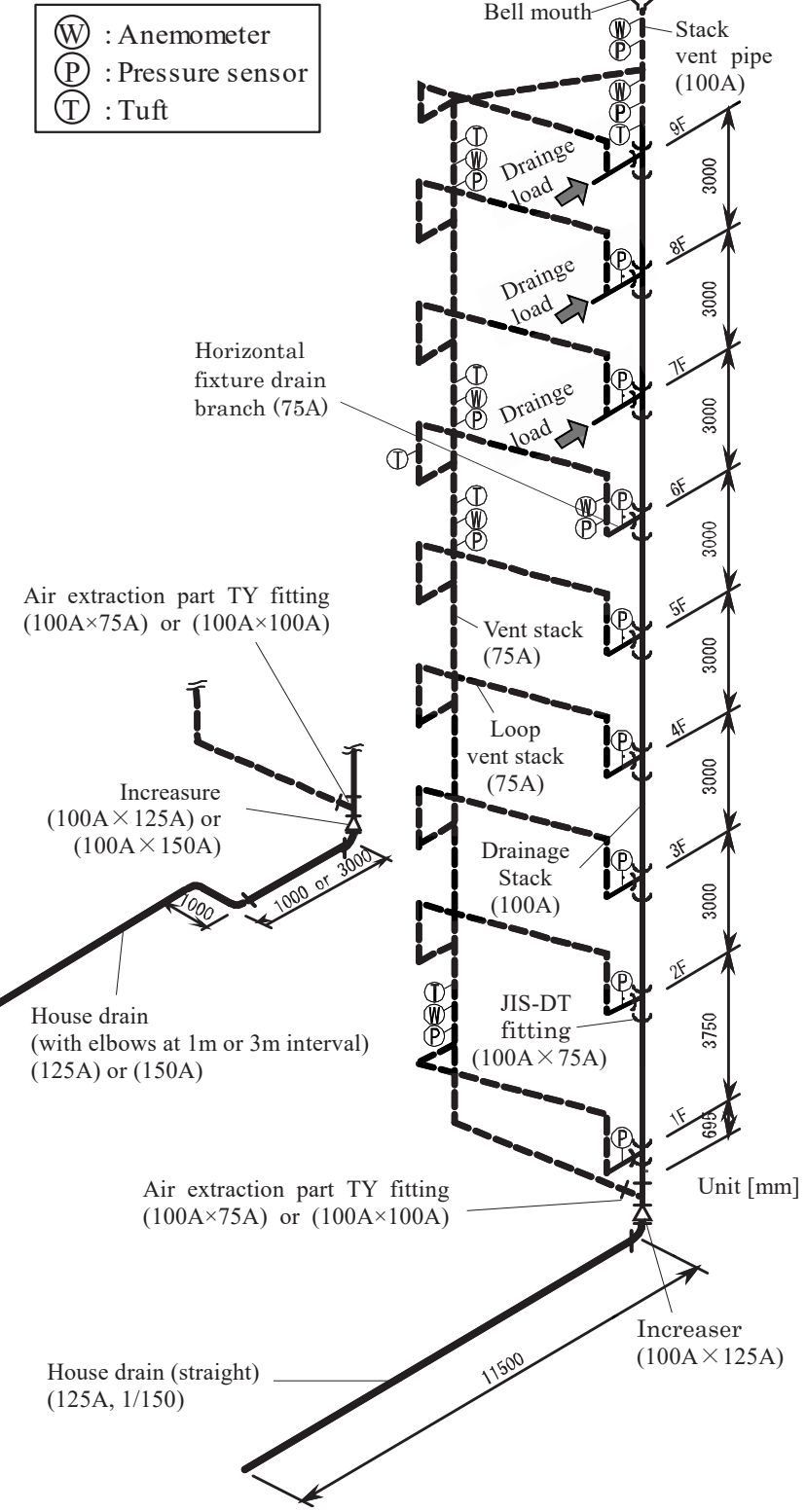

Fig. 1 Experimental drainage stack system

Table 1 Variations of the experimental drainage

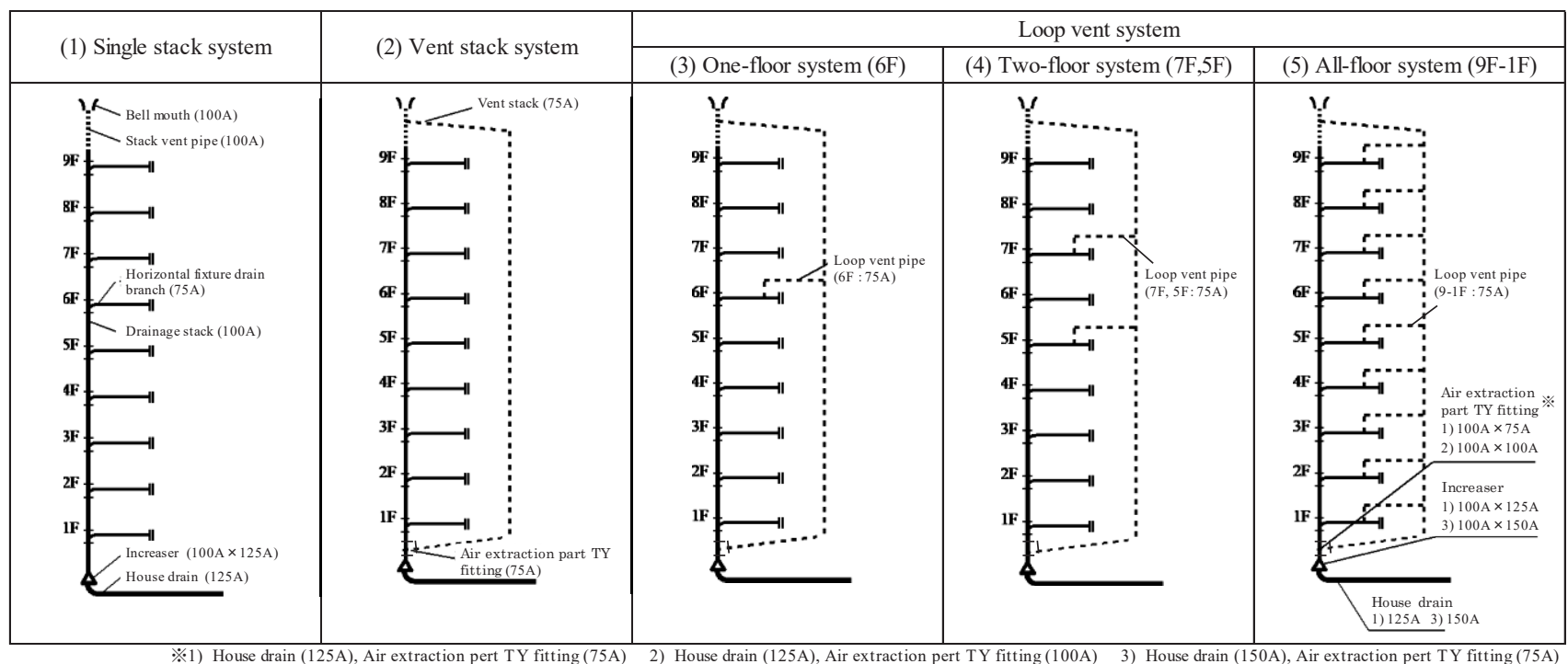


設置した 2 䇢所設置方式、全階に同様に設置した全䇢所設置方式の 系統図を示す。

\section{2 配管部位の差異による排水能力への影響把握実験}

供試実験システムとして、ループ通気方式の基準システムとなる Table 1(5)、Fig. 1 に示寸全箇所設置方式を用いる。排水負荷流量 の増加とともに、排水横主管の充水率が増加し、下層階での圧力変 動が大きくなりトラップの跳衫出し破封の可能性があるため、排水 横主管の管径を $150 \mathrm{~A}$ に拡径し、1m曲がり、3m曲がりを設けたシス テムでの実験も実施する。さらに、既往文献 3 でも推奨されている ように、排水横主管の管径を $125 \mathrm{~A}$ のまま、排水立て管基部からの通 気立て管の取出し部の TY 継手の管径のみ $75 \mathrm{~A}$ から $100 \mathrm{~A}$ に拡径し、 $75 \mathrm{~A}$ の通気立て管に接続した場合での検討も加える。また、同シス テムにおいて、通気立て管及びループ通気管の管径を $75 \mathrm{~A}$ から共に $50 \mathrm{~A}$ または $65 \mathrm{~A}$ に縮径した場合に排水能力へ及ぼす影響も検討する。

\section{3 排水負荷の与え方}

Table 1 の各供試排水立て管システムへの排水負荷の与え方は SHASE-S 218 に準拠し、Table 2 に示寸排水負荷・流量パターンのと おりとする。最上階（9階）より定流量負荷を $0.5[\mathrm{~L} / \mathrm{s}]$ 刻みで最大

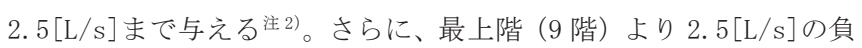
荷を与えた状態で、下層階（8階）より同様に排水負荷を合流させ、 同様に最終的には 9、8、7 階の 3 層からの合計排水負荷流量 $Q_{W}$ を 与え、その值が SHASE-S 206 に規定するループ通気方式(排水立て 管径 100A)の設計用許容流量 $6.7[\mathrm{~L} / \mathrm{s}]$ を超える $7.5[\mathrm{~L} / \mathrm{s}]$ まで実施す る。但し、2.2 で述べたように、排水横主管径を拡径し、その効果を 確認寸る場合には、さらに 6 階からの排水負荷も同様に加え 10. $0[\mathrm{~L} / \mathrm{s}]$ まで実施する。

\section{4 測定項目及び測定方法}

測定項目及び測定方法は、Fig. 1 中に示寸とおり、伸頂通気管内と 各階ループ通気管内、通気立て管内の管内中心風速変動を熱線風速 計で、伸頂通気管部と各階排水横枝管部等の管内圧力変動を圧力セ ンサで測定する。また、通気管内通気方向は、通気管各部において タフトを設置し、風向を確認する。通気流量 $Q a$ は、管内中心風速 変動の平均值に管断面積を乗じて算出する。また、Table 1 の各排 水立て管システムの排水能力 $Q S C$ (設計用許容流量) は、各階の排水

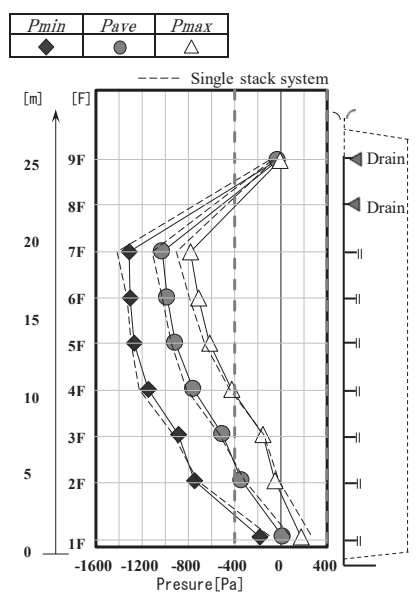

(1) Vent stack system

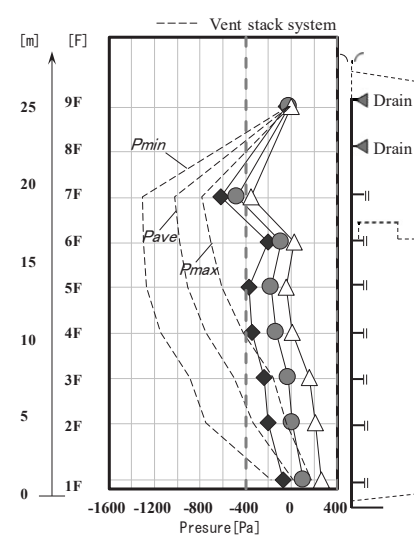

(2) One-floor system

横枝管内の圧力変動の最大值 $\operatorname{Pmax}(k)$ 、最小值 $\operatorname{Pmin}(k)$ 、平均值 Pave (k)から、システム全体における最大值、最小值となるシステム 最大圧力P P S max、システム最小圧力P P S I in を求め、両值が SHASE-S 218 の判定基準值となる $\pm 400[\mathrm{~Pa}]$ 以内におさまる範囲で排水可能 な最大合計排水負荷流量とする。

\section{3. 結果及び考察}

\section{1 各種通気方式における排水能力の把握}

\section{(1) 管内圧力の把握}

Fig. 2 に代表例として負荷階 9 階、8 階から各々 $2.5[\mathrm{~L} / \mathrm{s}] 、 Q_{W}$ が 5. $0[\mathrm{~L} / \mathrm{s}]$ の排水負荷を Table 1 に示寸排水立て管システム $(1 \mathrm{~m}$ 曲が り）に与えた場合のP P min (k)、P Pax (k)、Pave (k)を用いた管内圧力 分布を示す。ここで、 $Q_{W}$ が $5.0[\mathrm{~L} / \mathrm{s}]$ の場合を示した理由は、SHASES 206 の技術要項の設計例にもあるように、標準的なオフィスビル の基準階の男子便所に設置された大便器 3 個と小便器 3 個と、女子 便所の大便器 3 個が接続された排水横枝管から排水立て管に流入す る設計負荷流量が約 $2.5[\mathrm{~L} / \mathrm{s}]$ であり、それを 2 階層より与えた場合 に相当し、設計例も参考にしたことによる。同図は、排水横主管 $1 \mathrm{~m}$ 曲がりの場合で、破線で同図（1）に伸頂通気方式、同図（2）に通 気立て管方式、同図 (3) (4)に 1 䇢所通気方式、2 箇所通気方式の結 果を比較するために示す。これより、伸頂通気方式と通気立て管方 式では、管内圧力分布に差異はほとんど見られず、通気立て管の効 果は見られない。それに対して、同図 (2)、(3)のようにループ通気 管の設置箇所を 1 籄所、2 箇所と増やすことで、ループ通気管の設 置階で空気の給気や排気が行われることにより、管内圧力が緩和さ れ、2 箇所設置することで判定基準值となる $400[\mathrm{~Pa}]$ 以内におさま る。よって、この程度の排水負荷と規模の排水立て管システムにお いては上・中層階の 2 箇所にループ通気管を設置することで判定基 準值をクリアできると考えられる。さらに、全箇所設置では、管内

Table 2 Drainage load flow rate patterns

\begin{tabular}{|c|c|c|c|c|c|c|c|c|c|c|c|c|c|c|c|c|c|c|c|c|}
\hline \multirow{3}{*}{ Floor applied } & \multicolumn{20}{|c|}{ Drainage load flow rate $[\mathrm{L} / \mathrm{s}]$} \\
\hline & \multicolumn{5}{|c|}{ One-floor drainage } & \multicolumn{5}{|c|}{ Two-floor drainage } & \multicolumn{5}{|c|}{ Three-floor drainage } & \multicolumn{5}{|c|}{ Four-floor drainage* } \\
\hline & 0.5 & 1.0 & 1.5 & 2.0 & 2.5 & 2.5 & 2.5 & 2.5 & 2.5 & 2.5 & 2.5 & 2.5 & 2.5 & 2.5 & 2.5 & 2.5 & 2.5 & 2.5 & 2.5 & 2.5 \\
\hline $8 \mathrm{~F}$ & $\infty$ & $\lambda$ & 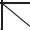 & 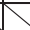 & & 0.5 & 1.0 & 1.5 & 2.0 & 2.5 & 2.5 & 2.5 & 2.5 & 2.5 & 2.5 & 2.5 & 2.5 & 2.5 & 2.5 & 2.5 \\
\hline $7 \mathrm{~F}$ & 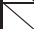 & 11 & 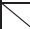 & 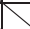 & & $D$ & $\lambda$ & N & $\Delta$ & 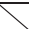 & 0.5 & 1.0 & 1.5 & 2.0 & 2.5 & 2.5 & 2.5 & 2.5 & 2.5 & 2.5 \\
\hline $6 \mathrm{~F}$ & & 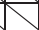 & S & S & 1 & $\triangle$ & $\Delta$ & S & N & 1 & $\Delta$ & 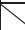 & $\Delta$ & $\Delta$ & S & 0.5 & 1.0 & 1.5 & 2.0 & 2.5 \\
\hline $\begin{array}{l}\begin{array}{l}\text { Total drainage } \\
\text { load flow rate }\end{array} \\
Q w[\mathrm{~L} / \mathrm{s}]\end{array}$ & 0.5 & 1.0 & 1.5 & 2.0 & 2.5 & 3.0 & 3.5 & 4.0 & 4.5 & 5.0 & 5.5 & 6.0 & 6.5 & 7.0 & 7.5 & 8.0 & 8.5 & 9.0 & 9.5 & 10.0 \\
\hline
\end{tabular}

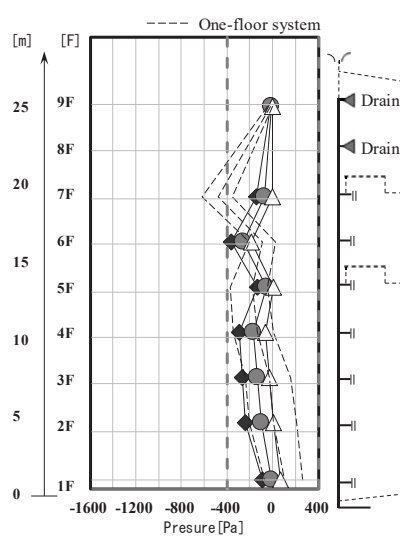

(3) Two-floor system

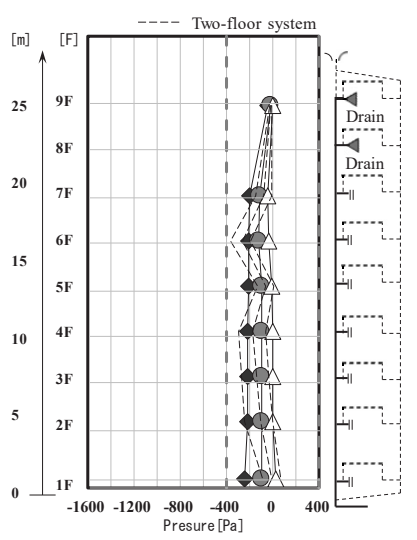

(4) All-floor system

Fig. 2 Comparison of internal pipe pressure distributions (When applying drainage loads from $9 \mathrm{~F}$ and $8 \mathrm{~F}$; total drainage load flow rate $5.0[\mathrm{~L} / \mathrm{s}]$ ) 
圧力はさらに緩和され、概ね $200[\mathrm{~Pa}]$ 以内におさまり、各階での変 動幅も均等になると見なせる。Fig. 3 に、Table 2 の排水負荷・流量 パターンの中の全同一排水負荷条件時において、伸頂通気方式を基 淮とした各排水立て管システムのシステム最小圧力 P Smin、システ ム最大圧力 $P_{S} \max$ の関係を示す。同図 (1)より排水横主管がストレ 一トの場合のP P S I in については、ループ通気管を 1 箇所に設置する だけで伸頂通気方式に対し 50\%程度、全箇所設置することで $70 \%$ 程度緩和できることがわかった。一方、同図 (2)より正圧発生におい て厳しい条件となる排水横主管曲がり $1 \mathrm{~m}$ の場合のP Psmax について は、2 箇所設置の場合に伸頂通気方式に対し正圧が $24 \%$ 増加したほ か、1 箇所設置や全箇所設置でも $13 \sim 16 \%$ の緩和にとどまり、通気 立て管方式の方が $42 \%$ の緩和となり、最も効果がある。2 箇所設置 の場合に正圧が増加した要因は、伸頂通気方式や 1 箇所設置の場合 と比較し、負圧が緩和され平均圧力は負圧側から正圧側に寄り、ル 一プ通気管の接続箇所が全箇所設置に比べ少ないため、下層階から の還気が不十分であり、正圧が十分に緩和されなかったものと考え られる。

\section{（2）通気流量の把握}

Fig. 4 に、合計排水負荷流量 $Q_{W}$ と各種通気方式における伸頂通 気管部の通気流量 $Q a$ の関係を示す。排水横主管がストレートの場 合に比べ、 $1 \mathrm{~m}$ 曲がりの場合には同一合計排水負荷流量において、排 水横主管部の抵抗が大きいため通気流量は小さく抑えられている。 排水横主管がストレートの場合は、ループ通気管の設置箇所数を増 加させて行くと、通気流量は同一合計排水負荷流量で比較しても 徐々に増えて行く傾向にある。ただし、2 䇢所設置の場合には 3.1(1) で述べた理由から、1 箇所設置の場合より通気流量が減少すること も確認できる。一方、排水横主管が $1 \mathrm{~m}$ 曲がりでは排水横主管部の通

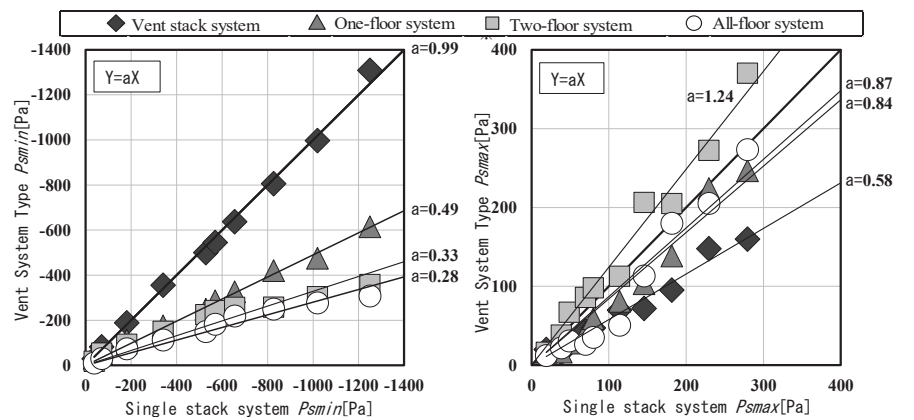

(1) $P$ smin (Straight)

(2) $P_{\text {smax }}($ Elbows at $1 \mathrm{~m})$

Fig. 3 Comparison of Psmax values and comparison of Psmin values

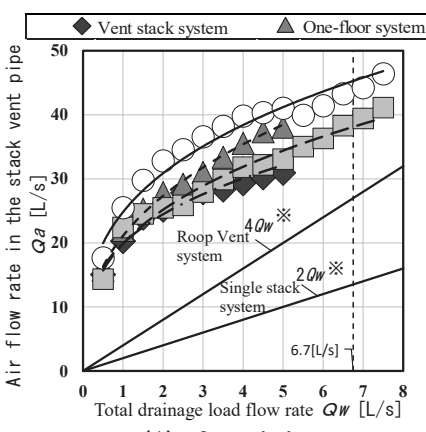

(1) Straight

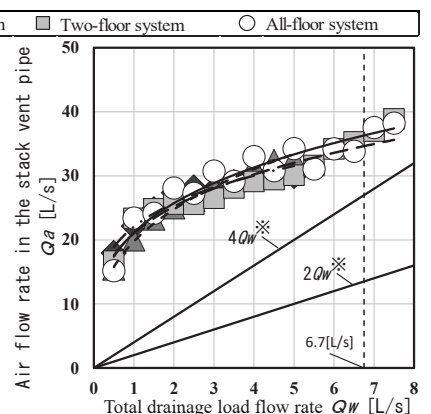

(2) Elbows at $1 \mathrm{~m}$
Fig. 4 Comparison of air flow rate in the stack vent pipe ※SHASE-S 206 Necessary Air flow rate

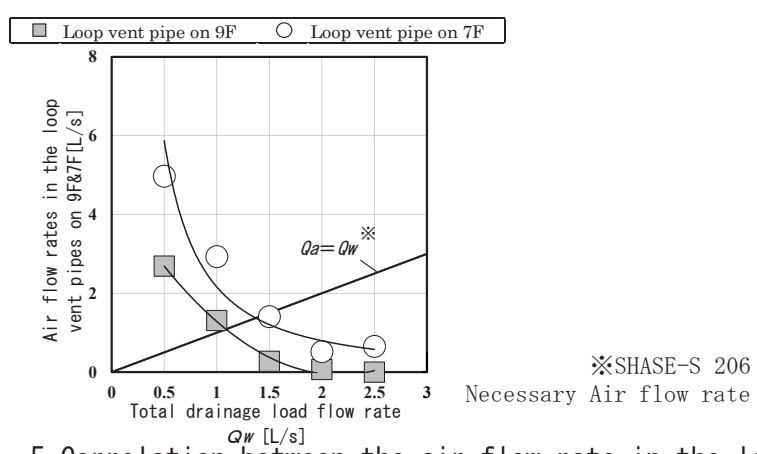

Fig. 5 Correlation between the air flow rate in the loop vent and the drainage load flow rate

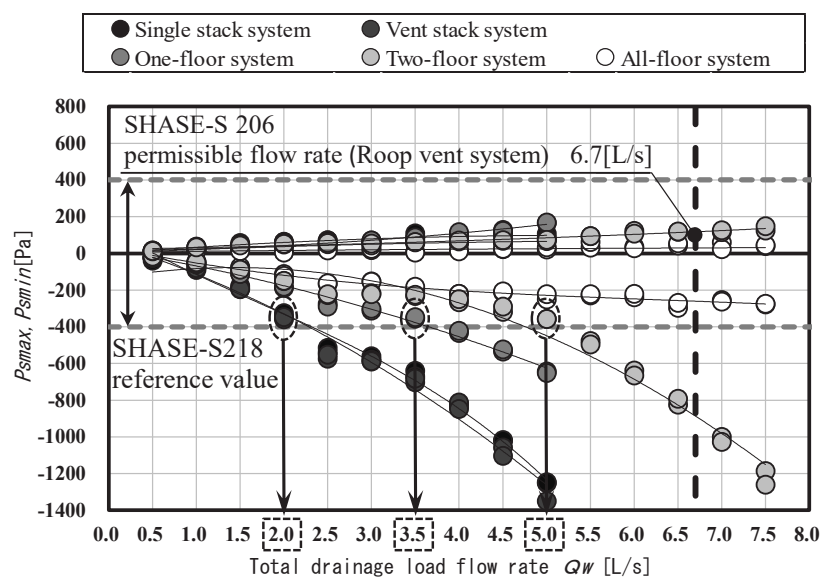

(1) Straight

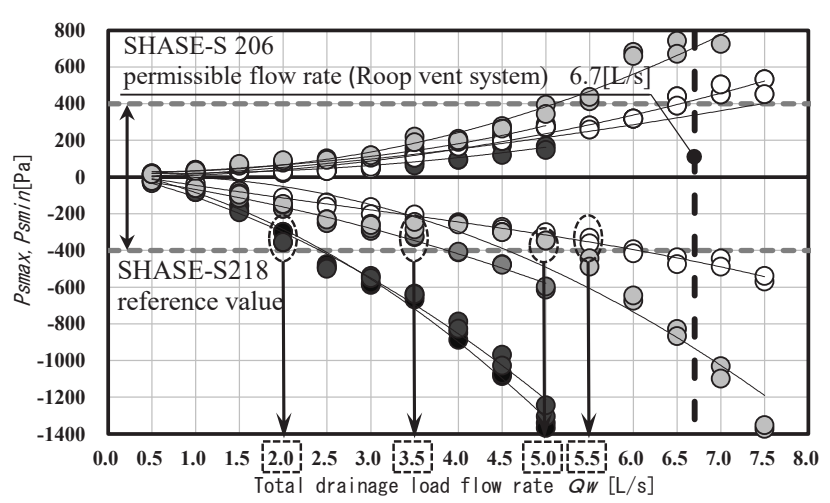

(2) Elbows at $1 \mathrm{~m}$

SHASE-S 206

permissible flow rate (Roop vent system) 6.7[L/s]

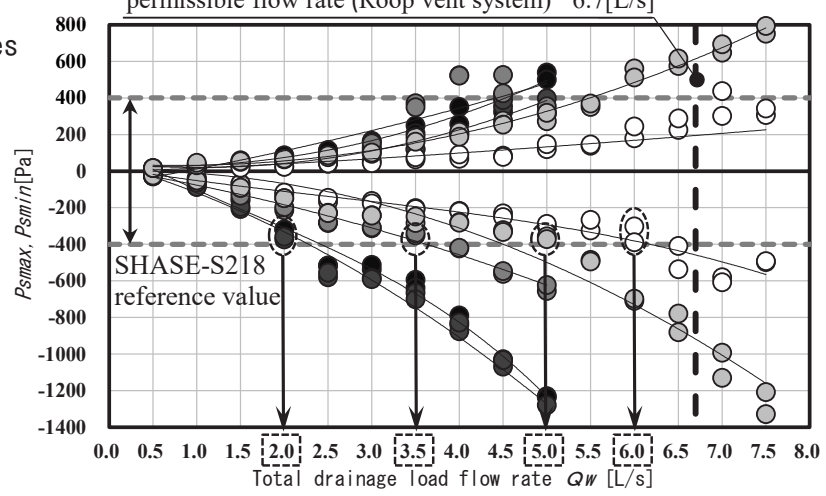

(3) Elbows at $3 \mathrm{~m}$

Fig. 6 Correlation of $Q w$ with Psmax and Psmin (Measured values) 
気抵抗が大きくループ通気管の効果は顕著には見られない。また、 Fig. 5 に排水負荷階となる 9 階、負荷階とならない 7 階の排水横枝 管に接続したループ通気管内の通気流量を示す。9 階では、排水負 荷流量が $2.0[\mathrm{~L} / \mathrm{s}]$ 以上で、排水横枝管内は、ほぼ満流となり、通気 の供給が困難となるものと考えられる。また、SHASE-S 206 におい ては各種通気方式において、各部位の設計用の必要通気流量を設定 しているが、Fig. 4 に伸頂通気方式 (排水負荷流量の 2 倍)、ループ 通気方式（排水負荷流量の 4 倍）の伸頂通気管における必要通気流 量線も示したが、実測值はそれらを大きく上回ることがわかる。 Fig. 5 に排水横枝管部のループ通気管での必要通気流量（排水負荷 流量と同流量）も示す。これらより、排水負荷流量に対する必要通 気流量は、SHASE-S 206 の計算值に対し、実際は、排水立て管の管 径 $100 \mathrm{~A}$ のループ通気方式の設計用許容流量が $6.7[\mathrm{~L} / \mathrm{s}]$ に対し、 伸頂通気管部で 5. 5 6.0 倍程度、排水横枝管内が半満流となる 1.0 $[\mathrm{L} / \mathrm{s}]$ 時のループ通気管部で $1.5 \sim 3.0$ 倍程度となり、実測值と SHASE-S 206 の算定值との間には乘離があることが確認できる。

\section{(3) 排水能力の把握}

Fig. 6 に各種通気方式の $Q_{W}$ と $P_{S} \operatorname{smin} 、 P_{S} \operatorname{smax}$ の関係を排水横主管 形態ごとに示す。これより、判定基準值より排水能力 $Q S C$ を求める と、伸頂通気方式、通気立て管方式で $2.0[\mathrm{~L} / \mathrm{s}] 、 1$ 䇢所通気設置で $3.5[\mathrm{~L} / \mathrm{s}] 、 2$ 箇所通気設置で $5.0[\mathrm{~L} / \mathrm{s}]$ となり、各方式共に排水横主

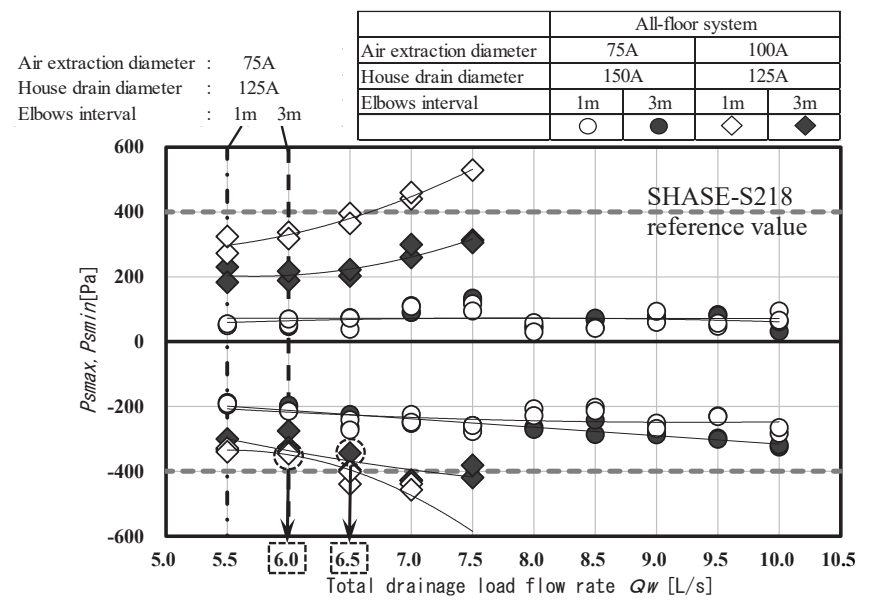

Fig. 7 Influence of expanded diameters of the house drain and the air extraction part (Measured values)

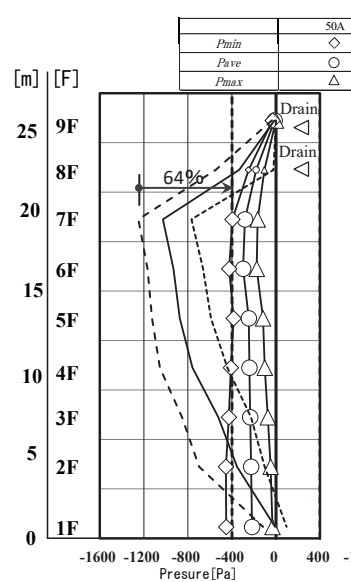

(1) $50 \mathrm{~A}$

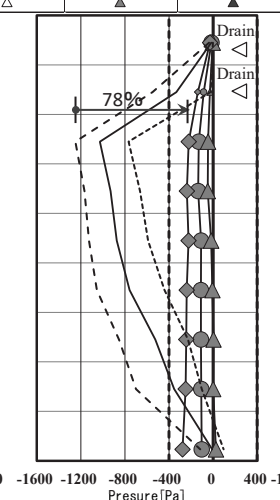

(2) $65 \mathrm{~A}$

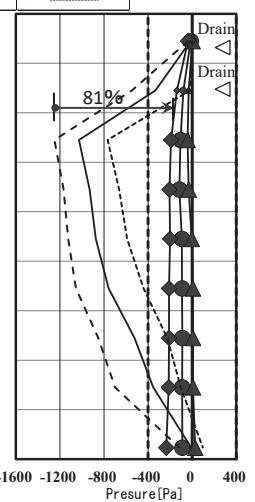

(3) $75 \mathrm{~A}$
Fig. 8 Comparison of distributions of internal pipe pressure in relation to vent pipe diameter

管の形態の影響を受けることなく、同一の值と見なせる。また、全 箇所設置では、それらより排水能力は大きくなり、排水横主管がス トレートでは $7.5[\mathrm{~L} / \mathrm{s}]$ 以上、 $1 \mathrm{~m}$ 曲がりで $5.5[\mathrm{~L} / \mathrm{s}] 、 3 \mathrm{~m}$ 曲がりで 6. $0[\mathrm{~L} / \mathrm{s}]$ と差異が生じる。特に実配管に近い排水横主管 $1 \mathrm{~m}$ 曲がり、 $3 \mathrm{~m}$ 曲がりにおいて、全箇所設置でも排水能力は、SHASE-S 206 の設 計用許容流量 $6.7[\mathrm{~L} / \mathrm{s}]$ に達しない。

\section{2 配管部位の差異による排水能力への影響把握}

\section{（1）通気立て管の取り出し方の影響}

Fig. 7 亿排水立て管の基部からの通気管取り出し部の管径の差異、 排水横主管の管径の差異がP P S I In、P S max 、さらにQSCに及ぼす影響 を比較して示す。前述までは、排水立て管の管径が $100 \mathrm{~A}$ に対し、排 水立て管基部からの通気立て管の取出し部の TY 継手の管径を $75 \mathrm{~A}$ としていたが、既往研究 ${ }^{3)}$ において排水立て管径と同一として取り 出すことが推奨されている。そこで、Fig. 7 に排水立て管と同じ $100 \mathrm{~A}$ で取出し、その後 $75 \mathrm{~A}$ の通気立て管へ縮径して接続した場合の結果 を示す。さらに取り出し部の管径は 75A のままであるが、排水横主 管の管径を $125 \mathrm{~A}$ から $150 \mathrm{~A}$ へと拡径した場合の結果も併記した。こ れより、1m曲がりで通気立て管の取出し部の管径が $75 \mathrm{~A}$ の場合では、 QSCは 5.5[L/s]（Fig.6(2)）であるのに対し、通気立て管の取出し 部の管径を $100 \mathrm{~A}$ に拡径することで正圧值が若干緩和され、排水能 力は $1 \mathrm{~m}$ 曲がりで $0.5[\mathrm{~L} / \mathrm{s}]$ 増加し $6.0[\mathrm{~L} / \mathrm{s}] 、 3 \mathrm{~m}$ 曲がりで $1.0[\mathrm{~L} / \mathrm{s}]$

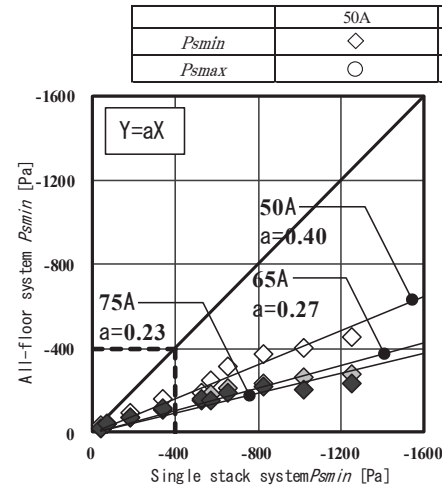

(1) Comparison of Psmin
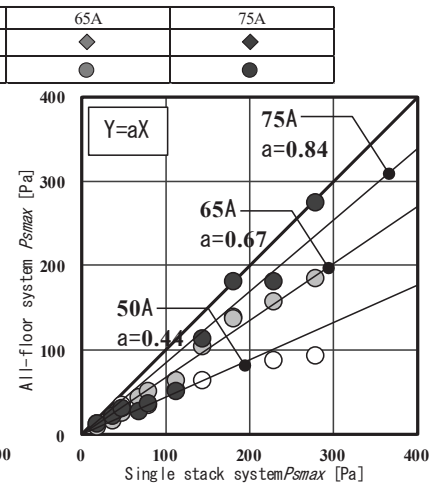

(2) Comparison of Psmax

Fig. 9 Influence of the vent pipe diameter on Psmin and Psmax

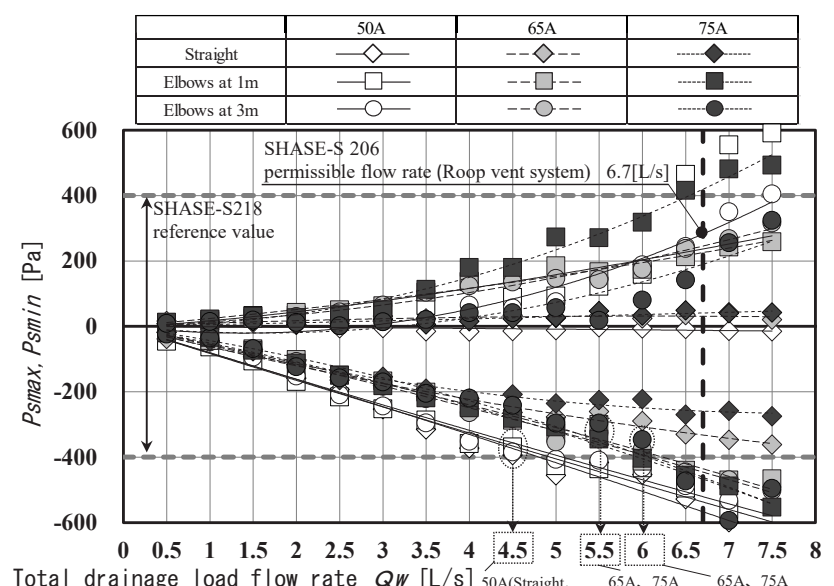

Total drainage load flow rate $Q W[\mathrm{~L} / \mathrm{s}]$ 50A(Straight, $65 \mathrm{~A}, 75 \mathrm{~A}$ 65A, $75 \mathrm{~A}$

Fig. 10 Correlation of the drainage load flow rate with Psmin and Psmax 


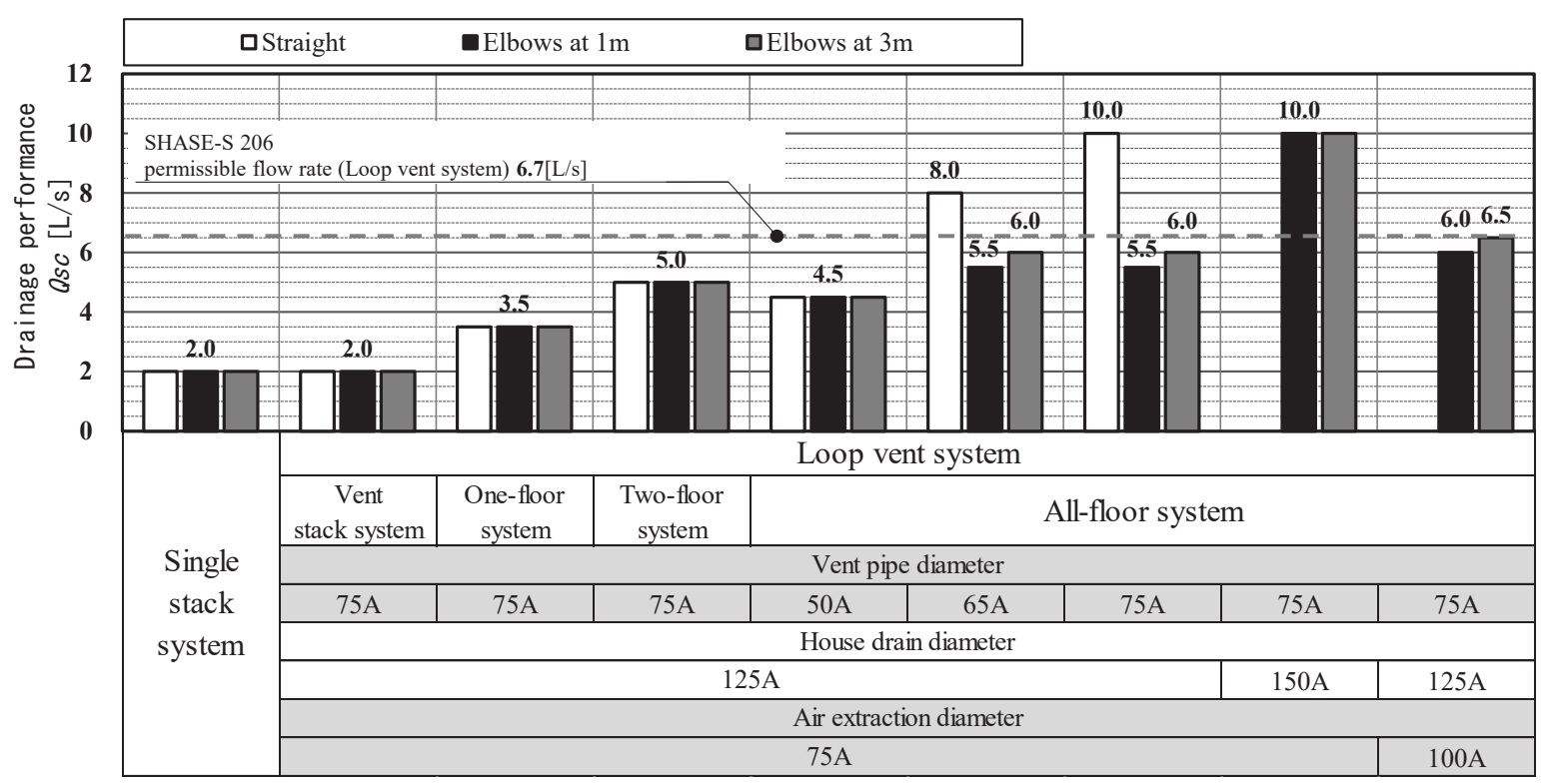

Fig. 11 Drainage performance comparison by type of system

増加し $6.5[\mathrm{~L} / \mathrm{s}]$ となる。また、排水横主管の管径を排水立て管の管 径に対し 2 サイズ拡径し $150 \mathrm{~A}$ とすると、排水能力は $10[\mathrm{~L} / \mathrm{s}]$ 以上の 効果が確保できる。よって、3.1(3)において、全䇢所設置でクリア できなかった設計用許容流量 $6.7[\mathrm{~L} / \mathrm{s}]$ に、通気立て管の取り出し部 の管径を拡径することで近づき、排水横主管の管径を拡径すること で、それを超える值となる。

\section{（2）ループ通気管と通気立て管径の差異の影響}

Fig. 8 に全箇所設置において、それに接続するループ通気管と通 気立て管の管径を両方とも 50A、65A、75A とし、Fig. 2 と同様に、 $Q_{W}$ として $5.0[\mathrm{~L} / \mathrm{s}]$ の排水負荷を与えた場合の管内圧力分布を示 す。これより、伸頂通気方式に比べ、P S S in は 50A で 64\%、65A で $78 \% 、 75 \mathrm{~A}$ で $81 \%$ 緩和されることがわかる。Table 1(5)の全箇所設 置において、Fig. 3 と同様に通気管の管径の差異がPSmin、PSmax 及ぼす影響を比較したものを Fig. 9 (1)、（2）に示す。これより、排 水横主管がストレートの場合のP S S I in については、伸頂通気方式に 対し、通気立て管及びループ通気管の管径が 50A で 60\%、65A で $73 \% 、 75 \mathrm{~A}$ で $73 \%$ の緩和効果があり、総合的に判断すると $65 \mathrm{~A} 、 75 \mathrm{~A}$ はほぼ同等と見なせる。また、P S Smax について、その傾向が逆転す る。これは、通気管径が小さい $50 \mathrm{~A}$ では通気抵抗が大きく、通気管 の管径がそれより大きい $65 \mathrm{~A} 、 75 \mathrm{~A}$ では、通気抵抗が小さい分、P S S in は緩和されるが、排水横主管内を通過する通気流量も増加し、PSmax が増加するものと考えられる。Fig. 10 に通気管の管径別に $Q_{W}$ と $P_{S m i n}$ と P S max の関係を示す。これより、50A では排水横主管形態の 影響を受けず全て $4.5[\mathrm{~L} / \mathrm{s}] 、 65 \mathrm{~A}$ と $75 \mathrm{~A}$ では排水横主管が $1 \mathrm{~m} 、 3 \mathrm{~m}$ 曲 がりで両径による QSC に差異はなく $5.5 \sim 6.0[\mathrm{~L} / \mathrm{s}]$ 程度、ストレー トでは $7.5[\mathrm{~L} / \mathrm{s}]$ 以上となるので、50A では Q SC は低下寸るが、65〜 $75 \mathrm{~A}$ では顕著な差異は見られずほぼ同等と見なせる。また、この程 度の排水横主管の形態では、QSC は P Smax (正圧)ではなく、PSmin (負 圧)で決定されることがわかる。

\section{3 排水能力 (設計用許容流量) の比較}

Table 1 に示した各種通気方式において、得られた排水能力 $Q S C$ をFig. 11 に整理して示す。また、同図には 3.2 に示寸排水通気管の
部位の差異による影響も考慮した場合の值も示寸。これより、伸頂 通気方式の排水能力 $2.0[\mathrm{~L} / \mathrm{s}]$ を基準值とすると、1 箇所、2 箇所の ループ通気管（75A）を設置することで $3.0 〜 5.0[\mathrm{~L} / \mathrm{s}]$ となり、 1.75 〜2.5 倍に排水能力は向上寸る。さらに、全箇所設置によって、排 水横主管形態や通気管径の影響により差異はあるが、確認できた排 水負荷の範囲で $5.5 \sim 10.0[\mathrm{~L} / \mathrm{s}]$ となり、2.75〜 5.0 倍に排水能力が 向上寸る。SHASE-S 218 による排水能力を許容流量とみなすと、排 水横主管がストレートである場合や排水横主管の管径を拡径する場 合を除けば、現行の SHASE-S 206 のループ通気方式の排水立て管径 $100 \mathrm{~A}$ の設計用許容流量 $6.7[\mathrm{~L} / \mathrm{s}]$ に対し、 $5.0 \sim 6.0[\mathrm{~L} / \mathrm{s}]$ となり、10 ～25\%程度低下寸る。よって、今後はループ通気管径や排水横主管 径なども考慮し、設計用許容流量を修正することが必要と考える。

\section{4 排水通気管路網モデルによる理論検討}

\section{(1) 管路網モデルの概要}

ここでは、基準システムとなる全箇所設置を例に、解析モデルを 提案し理論的な検討を行う。Fig. 12 に全箇所設置の管路網モデルを、 Fig. 13 にPave (k)を用いた管内圧力分布と区分説明図を、Fig. 14 に 各階圧力変動を考量した $P \min (k) 、 P \max (k)$ を求めるための説明図を 示寸。当該排水方式の管内平均圧力分布 Pave (k) は、Fig. 13 に示寸 ように各域に区分した。Fig. 12 の $\mathrm{A}$ 点〜 U 点の分岐点での通気流量 の収支式と式（1）〜（6）までの通気抵抗、吸引力を用いた同図の 11 個の閉回路の管内圧力のバランス式 $f(Q a i) \sim p(Q a i)$ より、各 部位の通気流量 $Q a i$ を求める。Fig. 15 に一例としてC、D、E、F の 閉回路を示すように、 $g(Q a i)$ の閉回路の管内圧力のバランス式（式 (7)）と各分岐点 C、D、E、F の $Q a$ の収支式となる $Q a_{(\mathrm{C})} 、 Q a_{(\mathrm{D})}$ 、 $Q a_{(\mathrm{E}) 、} Q a_{(\mathrm{F})}$ の算定式(式 $\left.(8) \sim(11)\right)$ を示す。同様に Fig. 12 に示し た B 点〜U 点についても算定式を作り、全点を流れる通気流量を逐 次近似法を用いて解析し、各部位(1)〜31)を流孔る全ての通気流量 Qai を求める。Fig. 16(1)、（2）に一例として、管内圧力を求める上 で必要な、解析上も特徽となる Fig. 13 中の通気抵抗係数 $\zeta$ (2) 排水 立て管単位長さ当たりの吸引力 $\Delta P_{1} / \triangle L_{1}$ について通気流量との関 係を示寸。同図 (1)より、通気流量の増加による（201 の変化が確認で 


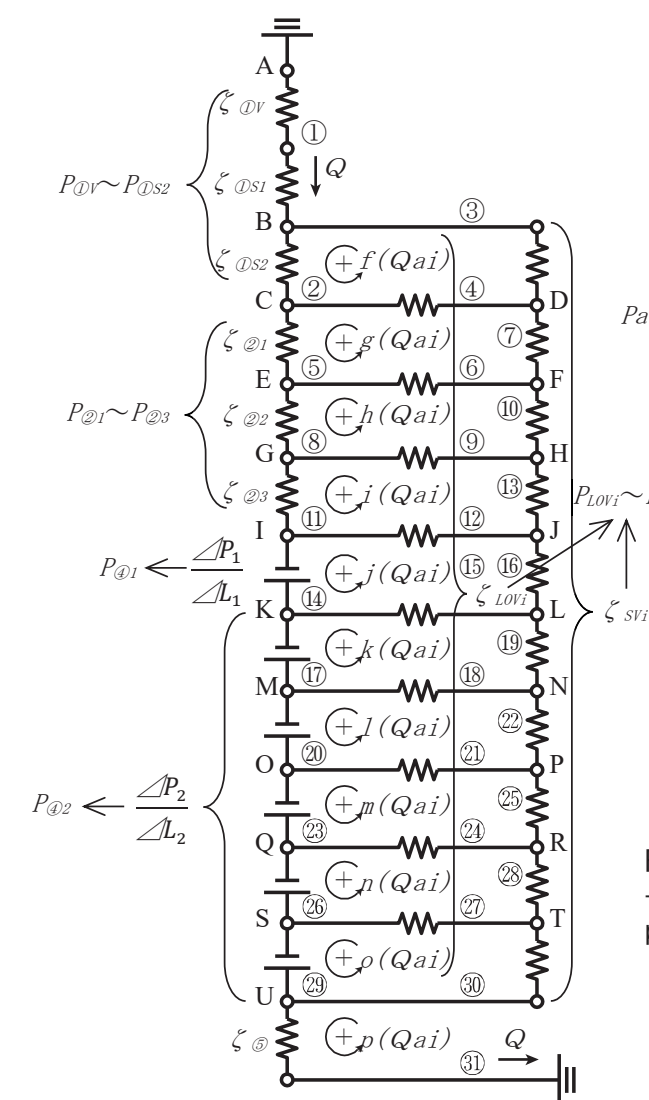

Fig. 12 Loop vent pipe network model adopting the all-floor system

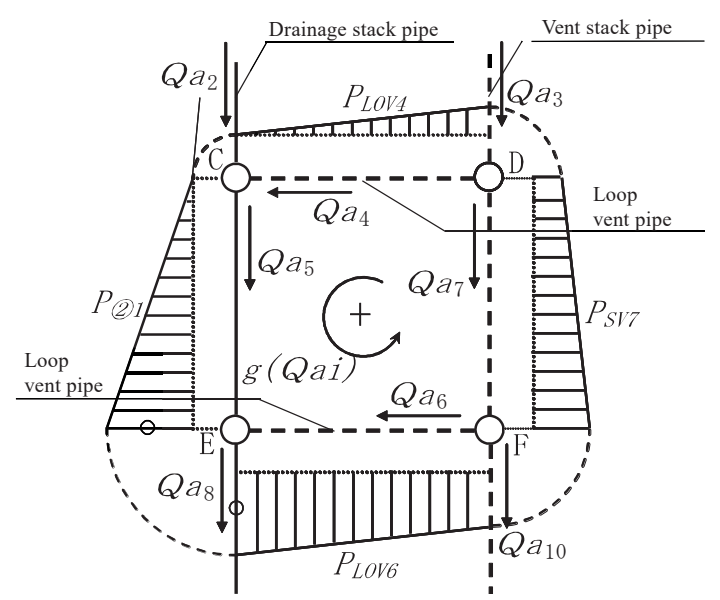

Fig. 15 A detailed section of the pipe network model (Closed circuit, $g($ Qai))

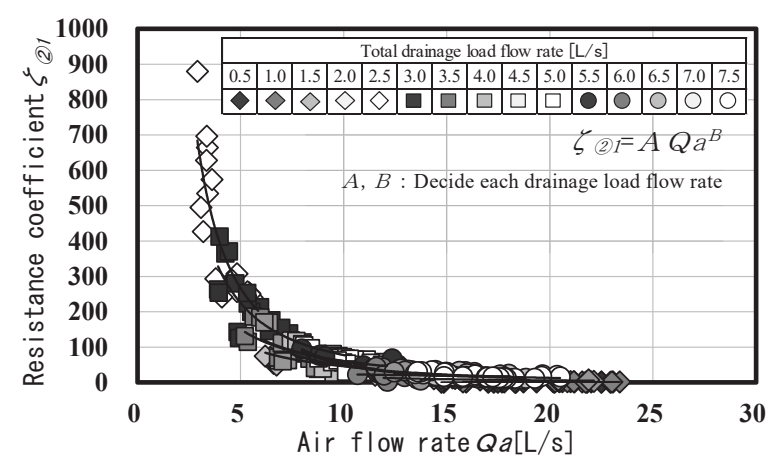

(1) Resistance coefficient $\zeta_{(2) 1}$ in region (2) 1

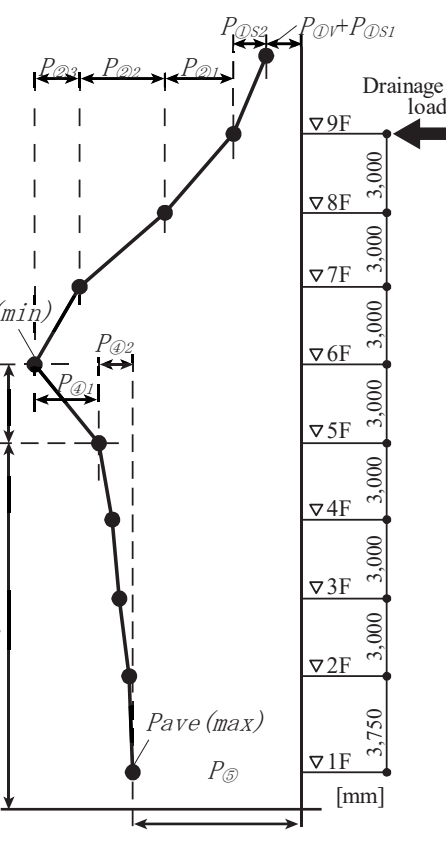

Fig. 13 Pressure distribution - explanatory diagram (Average pressure Pave)

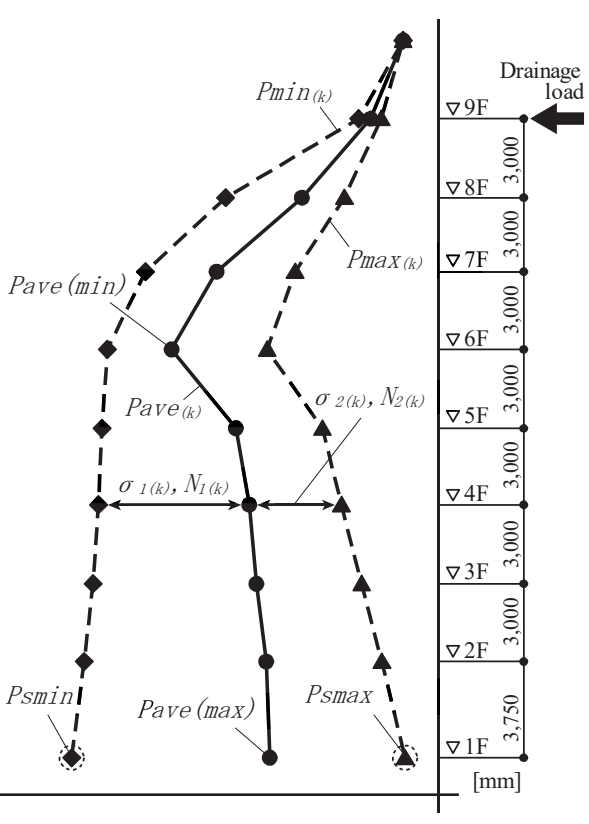

Fig. 14 Internal pipe pressure distribution - explanatory diagram $(P \max (k)$ and $P \min (k))$

$$
\begin{aligned}
& P_{(1) V(1) S 2}=\zeta_{(1) V \sim(1) S 2} \times \frac{\rho}{2} \times\left(\frac{Q a}{A_{S}}\right)^{2} \quad \cdots \cdot \text { 式 (1) } \\
& P_{(2) 1 \sim(2) 3}=\zeta_{(2) 1 \sim(2) 3} \times \frac{\rho}{2} \times\left(\frac{Q a i}{A_{s}}\right)^{2} \quad \cdots \cdot \text { 式 (2) } \\
& P_{(4)}=\left(\triangle P_{1} / \triangle L_{1}\right) \times L_{1} \\
& \text { ・・式 (3) } \\
& P_{(4) 2}=\left(\Delta P_{2} / \Delta L_{2}\right) \times L_{2} \\
& \text { ・・式 (4) } \\
& P_{(5)}=\zeta_{(5)} \times \frac{\rho}{2} \times\left(\frac{Q a}{A_{H}}\right)^{2} \\
& P_{\text {LOVi } \sim S V i}=\lambda \times \frac{\rho}{2} \times\left(\frac{Q a i}{A_{B}}\right)^{2} \\
& \cdots \text { 式 (5) } \\
& \text { ・・式 (6) }
\end{aligned}
$$

各分岐点における $Q a$ の収支式

$$
\begin{array}{lc}
Q a_{(\mathrm{C})}: Q a_{5}-Q a_{2}-Q a_{4}=0 & \cdots \cdot \text { 式 (8) } \\
Q a_{(\mathrm{D})}: Q a_{7}+Q a_{4}-Q a_{3}=0 & \cdots \cdot \text { 式 (9) } \\
Q a_{(\mathrm{E})}: Q a_{8}-Q a_{5}-Q a_{6}=0 & \cdots \cdot \text { 式 (10) } \\
Q a_{(\mathrm{F})}: Q a_{10}+Q a_{6}-Q a_{7}=0 & \cdots \cdot \text { 式 (11) }
\end{array}
$$

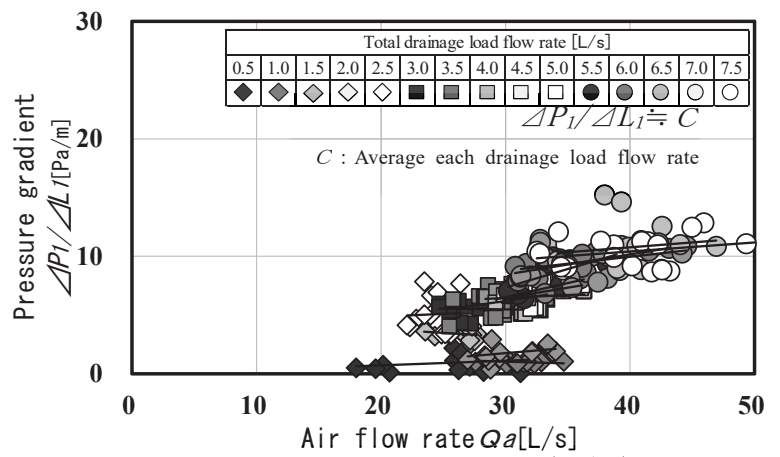

(2) Pressure gradient $\triangle P_{1} / \Delta L_{1}$

Fig. 16 Correlation among air flow resistance coefficient, pressure gradient and air flow rate 
き、負荷流量ごとに回帰式を求めて用いる。また、同図 (2)では、通 気流量による $\triangle P_{1} / \Delta L_{1}$ の変化が小さいため、負荷流量ごとに平均值 を求め用いる。管路網の他の通気抵抗係数、吸引力も同様に求め用 いる。

\section{（2）通気流量の予測}

3. 3 で提案した管路網モデルを解析し、(1)～(31)の各点を流れる通 気流量Q Q a の計算を行い、得られた結果を実測值と比較して Fig. 17、 Fig. 18 に示す。同図 (1)、（2）に示寸ループ通気方式の排水立て管部 とループ通気管部の比較では両方とも $\pm 20 \%$ 程度の範囲にあり、全 排水負荷流量について算出した結果について、実測值に対する計算 值のばらつきの程度が把握できた。

\section{（3）管内圧力分布の予測}

算出した Q ai より各点の管内平均圧力P P v e (k)を求め、一例として Fig. 19 に全階設置方式で $Q W$ が $5.0[\mathrm{~L} / \mathrm{s}] 、 7.5[\mathrm{~L} / \mathrm{s}]$ の管内圧力分 布の実測值と予測值を比較して示す。また、Fig. 20、Fig. 21 に、す べての排水負荷・流量パターンでの平均圧力の最小值 Pave (min)、 最大值 Pave (max)についても同様に比較して示す。これより、Fig. 17、2 Fig. 18 のように通気流量にばらつきはあるが、一部を除けば Pave(min)は土10\%程度の範囲におさまる。Pave (max)は 10\%を超え る值があるものの、負圧域で-30 $[\mathrm{Pa}]$ 以下と小さいため管内圧力とし て支障のないものと判断する。次に、Fig. 14 に示すように $P \max (k)$ 、 $\operatorname{Pmin}(k)$ を Pave $(k)$ と変動成分 $\sigma_{1(k)} \times N_{1(k)} 、 \sigma_{2(k)} \times N_{2(k)}$ をを用いて、 式(12) 式(13) から算出する。なお、 $N_{I(k)}$ および $N_{2(k)}$ の数值は、 1 階 から 9 階までの全階の平均值で $N_{l(k)}$ は 3.3、 $N_{2(k)}$ は-3.8 を用いる。 $\operatorname{Pmax}_{(k)}=\operatorname{Pave}_{(\mathrm{k})}+\sigma_{1(\mathrm{k})} \times N_{1(\mathrm{k})}$ ・・式 (12) $\operatorname{Pmin}_{(k)}=$ Pave $_{(k)}+\sigma_{2(k)} \times N_{2(\mathrm{k})}$ ・・式 (13)

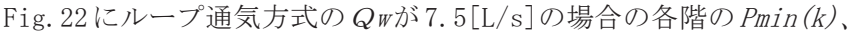
$P \max (k)$ による管内圧力分布の実測值と予測值を Fig. 19 と同様に比 較して示す。同図より、P $\min (k)$ では、概ね一致しているが、排水横 主管 $1 \mathrm{~m}$ 曲がりの場合に下層階のP S Smax が $50[\mathrm{~Pa}$ 程度の誤差が生じ る。他の $Q_{W}$ についても同様に圧力分布を描き、排水能力の判定基 準となるP S Smin、PSImax を読みとる。Fig. 23、Fig. 24 に全ての $Q_{W}$ の $P_{S}$ min とP S Smax の実測值と予測值を比較し示す。Fig. 23 のP Smin で 判断すると、排水横主管がストレート、1m 曲がりの場合ともに、実 測值と予測值の誤差は概祆 $\pm 10 \%$ 以内におさまるが、Fig. 24 に示す $P_{S}$ max 2 では、排水横主管が $1 \mathrm{~m}$ 曲がりの場合、判定基準值となる $400[\mathrm{~Pa}]$ 付近で誤差は 10 20\%程度に広がる。よって、排水横主管

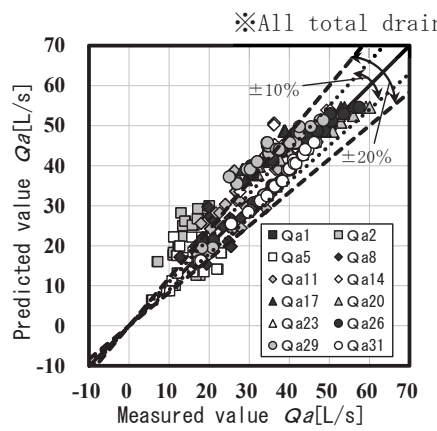

(1) Drainage stack

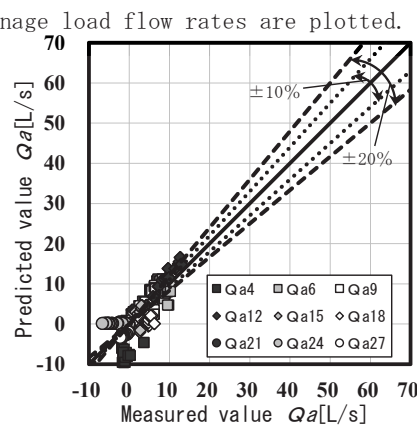

(2) Loop vent pipe

Fig. 17 Comparison between measured and predicted airflow rates (Straight)

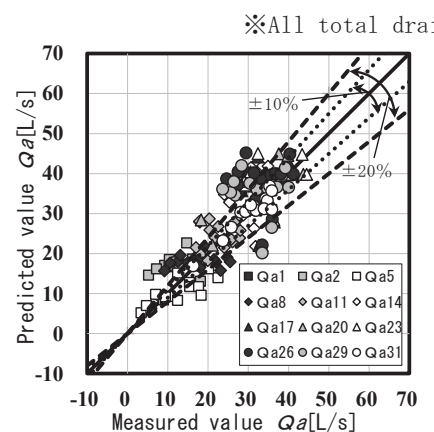

(1) Drainage stack

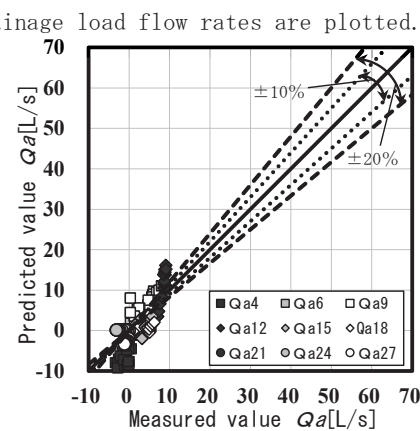

(2) Loop vent pipe

Fig. 18 Comparison between measured and predicted airflow rates (With elbows at $1 \mathrm{~m}$ intervals)

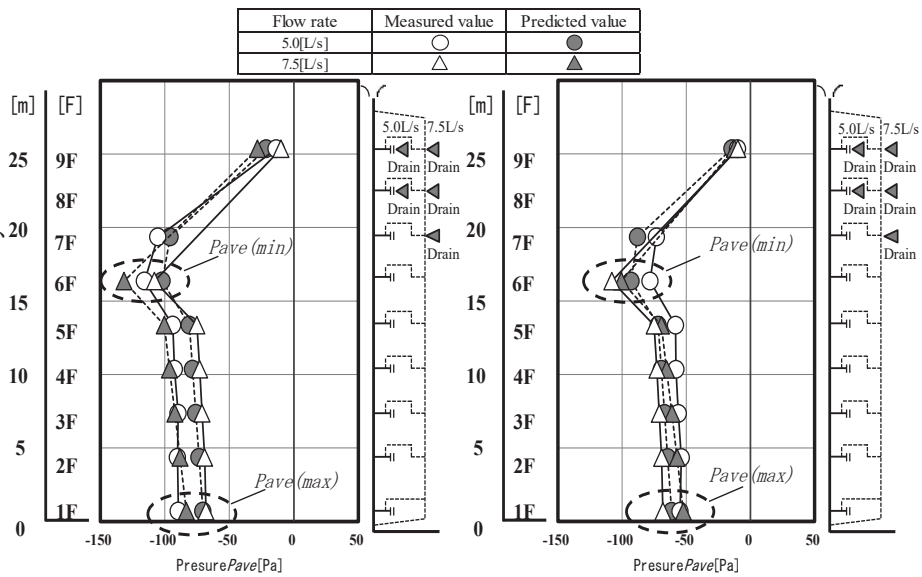

(1) Straight

(2) Elbows at $1 \mathrm{~m}$

Fig. 19 Comparison of measured and predicted internal pipe pressure (Pave)

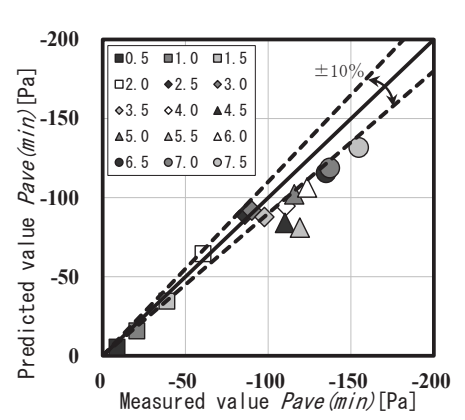

(1) Straight

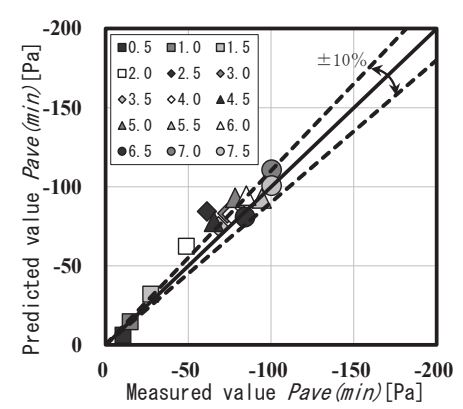

(2) Elbows at $1 \mathrm{~m}$

Fig. 20 Comparison between measured and predicted Pave (min) values

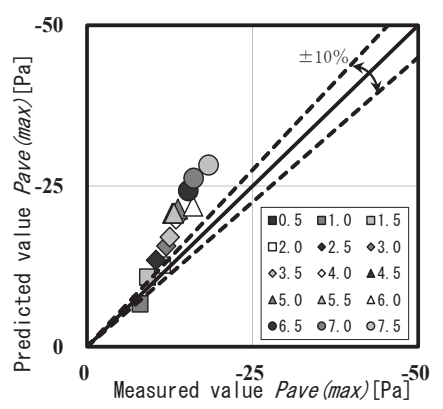

(1) Straight

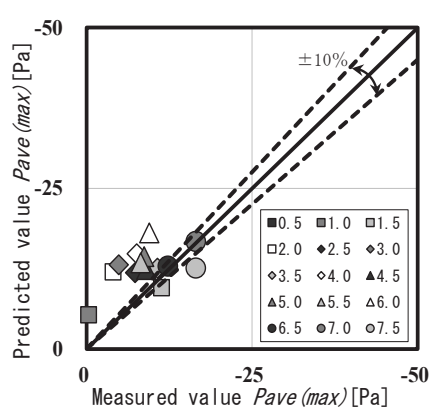

(2) Elbows at $1 \mathrm{~m}$

Fig. 21 Comparison between measured and predicted Pave(max) values 


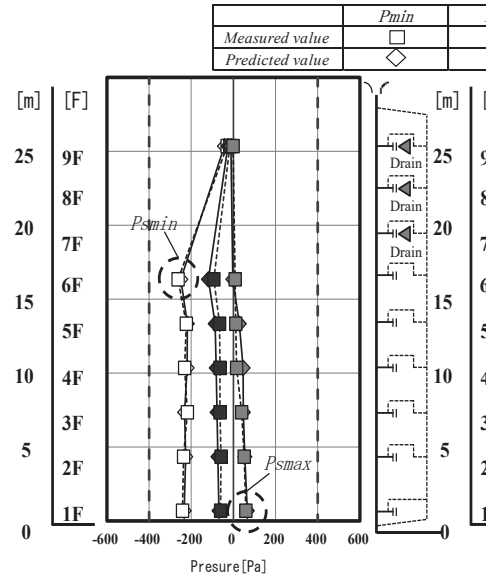

(1) Straight

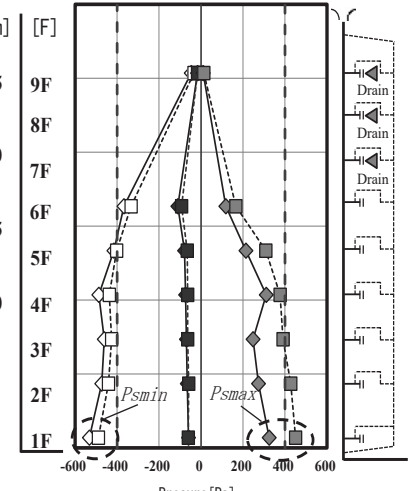

(2) Elbows at $1 \mathrm{~m}$
Fig. 22 Comparison of measured and predicted internal pipe pressure Drainage load flow rate $7.5[\mathrm{~L} / \mathrm{s}]$

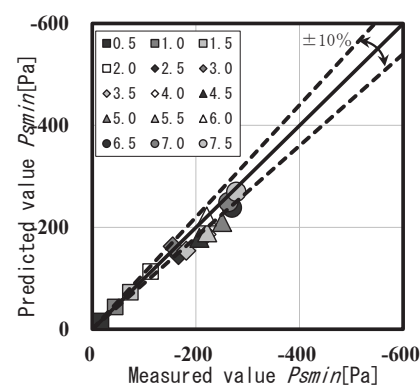

(1) Straight

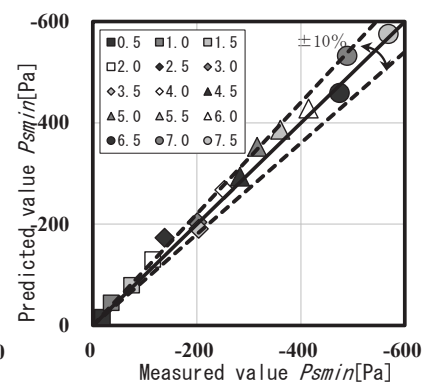

(2) Elbows at $1 \mathrm{~m}$
Fig. 23 Comparison between measured and predicted Psmin values

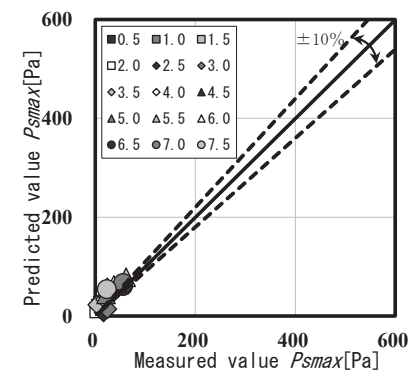

(1) Straight

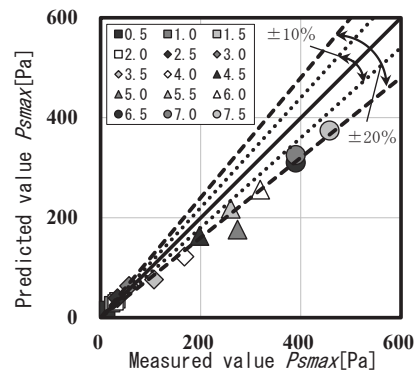

(2) Elbows at $1 \mathrm{~m}$
Fig. 24 Comparison between measured and predicted Psmax values

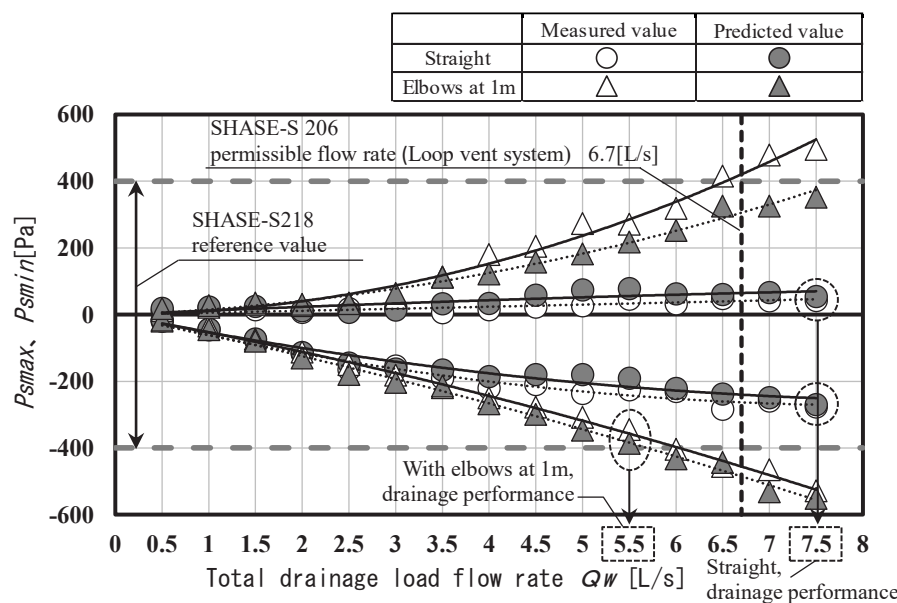

Fig. 25 Comparison between measured and predicted drainage performance values
に $1 \mathrm{~m}$ 曲がりを有する場合、約 10～20\%程度の誤差を考慮する必要 がある。誤差の原因は、計算に用いる Fig. 12、Fig. 13 に代表例を示 した各区分域の通気抵抗と吸引力の精度、各階の変動成分の差にあ ると考えられる。

\section{（4）排水能力の予測}

F ig. 25 に、全箇所設置の場合の $Q_{W}$ と実測值及び計算值のP S S I in 、 $P S$ Smax の関係を示す。これより、PS S I in は実測值と予測值の誤差は 小さいが、P S Smax $Q_{W}$ の増加に伴い誤差が大きくなる。しかし、予 測值の排水能力 $Q S C$ は、P PSmin 值で排水能力が決定され排水横主管 がストレートでは $7.5[\mathrm{~L} / \mathrm{s}]$ 以上、 $1 \mathrm{~m}$ 曲がりでは $5.5[\mathrm{~L} / \mathrm{s}]$ 程度の值 となり、実用上は実測值と概水一致する。PS m max 值においては精度 に課題が残るものの、全箇所設置の排水・通気管路網の計算を、よ り多層のシステムへ展開する上で、有効な手段となるもの考えられ る。

\section{4. まとめ}

高層建築への適用を目的とした各種ループ通気方式の排水立て管 システムへSHASE-S 218 による排水能力試験を実施した。その結果 より、排水能力を実験的に把握するとともに、それを推定する管路 網モデルへの適用の可能性について検討した結果、以下の知見を得 た。

（1）排水横枝管と通気立て管とを結ぶループ通気管の設置箇所を 1 箇所、2 箇所、全階とした場合における圧力分布の変化を把握し、 設置箇所の変更に伴う伸頂通気方式に対するシステム最大值・最小 值の増減を定量的に把握した。

（2）（1）に関連して、伸頂通気管部及びループ通気管部を通過する 通気流量は、SHASE-S 206 定常流量法で計算される必要通気流量よ り同一排水負荷流量に対し大きな值となることを指摘し、その值を 定量的に示した。

（3）各種ループ通気方式における排水能力を定量的に把握できた。 その結果より、排水横主管がストレートの場合以外となる $1 \mathrm{~m} 、 3 \mathrm{~m}$ 曲 がりでは、SHASE-S 206 のループ通気方式の設計用許容流量を下回 ることがわかった。ただし、排水立て管からの通気立て管の取り出 し部、排水横主管の管径を拡径させることでSHASE-S 206 の設計用 許容流量に概社達することがわかった。よって、現行の SHASE-S 218 におけるループ通気方式の設計用許容流量は、ループ通気管径や排 水横主管径を考慮して決定する必要があることを指摘した。

（4）既報 7) 9) で提案した通気流量と管内圧力の管路網解析モデル を拡張させ、ループ通気方式（全箇所設置）の解明に適用した。そ の結果、排水横主管に曲がり抵抗がある場合にシステム最大値（正 圧）が計算值と実測值の誤差が大きくなるが、ストレート配管にお いては管路網解析モデルの適用が可能と考えられ排水能力の推定が 可能である。今後の課題として、排水横主管に曲がりを有する場合 の下層階に発生する正圧について、計算精度を向上させるために、 管路網解析モデルを構成する部位の通気抵抗と吸引力、変動成分の 詳細な検討を行う必要がある。

注

注 1) ループ通気方式におけるループ通気管の機能は、排水横枝管に接続され た複数の衛生器具の排水によって排水横枝管上で生ずる誘導サイフォン作 
用の防止であるとともに、伸頂通気方式に比べ、排水立て管システムの排 水能力、設計用許容流量を増加させるためにも有効である。本研究は、主 に後者の究明に主眼を置いたものである。

注 2）SHASE-S 218 は、主に集合住宅用排水立て管システムの排水能力を把握 することを目的とした試験法であるが、今回は業務用建物を対象としたル 一プ通気方式に適用した。その理由は、現試験法は定流量負荷が用いられ ているが、既往研究 ${ }^{11}$ の成果などから、実際の住宅用の器具排水負荷に比 心゙、かなり厳しい条件での負荷になることが指摘されている。よって、連 立大便器等が設置され、住宅に比べ排水立て管へ流入する排水負荷が多い 業務用建物へも適応できるものと判断し採用した。

\section{参考文献}

1) MASAO Ishihara : A Study of a Vent Characteristics of Vent Stack (Report 1), Summaries of Technical Papers of Annual Meeting, Architectural Institute of Japan, pp.401 402, 1973.10 (in Japanese)

石原正雄: 排水通気管系の通気特性に関する研究 1 . 伸頂通気管の通気特 性, 日本建築学会大会学術講演梗概集, pp. 401 402, 1973. 10

2) TERU Abe : An Experimental Study of indoor Vent Stack on Super High-rise Apartment About the Design Flow Rate on High-rise Apartment (Report 2)Summaries of Technical Papers of Annual Meeting, Architectural Institute of Japan, pp.133 134, 1972.10 (in Japanese)

阿部照: 屋内排水通気設備の実験的研究 (2) 高層集合住宅における排水設計 流量について，日本建築学会大会学術講演梗概集，pp. 133～134，1972. 10

3) NOBUYUKI Tsukagoshi :, Problems of Testing of Drainage System, Technical Papers of Annual Meeting the Society of Heating, Air-Conditioning and Sanitary Engineers of Japan, pp.257〜260, 1979.10 (in Japanese).

塚越信行: 排水システムの実験とその問題点, 空気調和・衛生工学会学術 講演会論文集，pp. 257〜260，1979. 10

4) National Plumbing Code Handbook, Edited by Vincen T.Manas, 1957

5) JA Swaffield and LS Galowin : The Engineering Design of Building Drainage System, Chapter5 Vent system design, Chapter5:Vent system design, pp.115 150, 1992

6) MASAYUKI Otsuka et al. : A Study of a Method for Predicting the Drainage Performance of Loop Vent Drainage Systems, Proceedings of the 38th International Symposium of CIB W062, pp.205 221, 2012.8, Edinburgh

7) MASAYUKI Otsuka et al. : Study of the Performance Evaluation of Air Admittance Valves by Means of the Drainage Capacity Prediction Method for Drainage Stack Systems : Influences on Vent Characteristics of Air Admittance Valves (AAVs) and Drainage Capacities, Journal Environmental Engineering (Transactions of AIJ), Vol. 73 No. 628, pp.783 790, 2008.6 (in Japanese)

8) MASAYUKI Otsuka et al. : Examination of Drainage Performance When An air Admittance Valve is Applied in One Location Along the Horizontal Fixture Branch : Study on the Drainage Performance and a Method for Predicting the Same of a High-Rise Stack Drainage System Having Air-Admittance Valves Installed to the Vent Pipe and the Horizontal Fixture Drain Branch (Report 1), Journal Environmental Engineering (Transactions of AIJ), Vol. 77 No. 674, pp.275 282, 2012.4 (in Japanese)

9) MASAYUKI Otsuka et al. : Examination of Drainage Performance When An airAdmittance Valve is Applied in Multiple Locations Along the Horizontal Fixture Drain Branch : Study on the Drainage Performance and a Method for Predicting theSame of a High-Rise Stack Drainage System Having Air-Admittance Valves Installed to the Vent Pipe and the Horizontal Fixture Drain Branch (Report 2), Journal Environmental Engineering (Transactions of AIJ), Vol. 78 No. 693, pp.849 857, 2013.11 (in Japanese)

10) John Swaffield : Transient Airflow in Building Drainage System, pp292, 2010

11) MASAYUKI Otsuka et al. : The potential of a new drainage system with special resin fittings for multiple water-saving toilet units in commercial buildings, Proceedings of the 43rd International Symposium of CIB W062 Water Supply and Drainage for Buildings, pp.130 141, 2017.8, Netherlands
本報使用の記号と単位

\begin{tabular}{|c|c|}
\hline$P_{(\mathbb{C} V}$ & : 伸頂通気管端部の圧力損失 $[\mathrm{Pa}]$ \\
\hline$P_{(\mathbb{D S} 1}$ & :伸頂通気管直管部の圧力損失 $[\mathrm{Pa}]$ \\
\hline$P_{(1) S 2}$ & :伸頂通気管分岐部の圧力損失 $[\mathrm{Pa}]$ \\
\hline$P_{(2) \sim(2) 3}$ & : 最大負圧域の圧力損失 $[\mathrm{Pa}]$ \\
\hline$P_{(3)}$ & :排水横主管部の圧力損失 $[\mathrm{Pa}]$ \\
\hline$P_{(\oplus 1}$ & : 中層階の吸引力 $[\mathrm{Pa}]$ \\
\hline$P_{(72}$ & :下層階の吸引力 $[\mathrm{Pa}]$ \\
\hline$P_{\text {LOVi }}$ & :ループ通気管内の圧力損失 $[\mathrm{Pa}]$ \\
\hline$P_{S V i}$ & :通気立て管内の圧力損失 $[\mathrm{Pa}]$ \\
\hline$\zeta$ (1) & : 伸頂通気管端部の通気抵抗係数 \\
\hline$\zeta \otimes S I$ & :伸頂通気管直管部の通気抵抗係数 \\
\hline$\zeta \bowtie S 2$ & :伸頂通気管分岐部の通気抵抗係数 \\
\hline$\zeta(21 \sim(2) 3$ & :最大負圧域の通気抵抗係数 \\
\hline$\zeta(5)$ & :排水横主管部の通気抵抗係数 \\
\hline$\triangle P_{1} / \triangle L_{1}$ & :中層階の排水立て管 $1 \mathrm{~m}$ 当たりの吸引力 $[\mathrm{Pa} / \mathrm{m}]$ \\
\hline$\triangle P_{2} / \triangle L_{2}$ & :下層階の排水立て管 $1 \mathrm{~m}$ 当たりの吸引力 $[\mathrm{Pa} / \mathrm{m}]$ \\
\hline$L_{1}$ & : 中層階の排水立て管の長さ [m] \\
\hline$L_{2}$ & :下層階の排水立て管の長さ $[\mathrm{m}]$ \\
\hline$\rho$ & :空気密度 $\left[\mathrm{kg} / \mathrm{m}^{3}\right]$ \\
\hline$A_{S}$ & : 伸頂通気管と排水立て管の断面積 $\left[\mathrm{m}^{2}\right]$ \\
\hline$A_{H}$ & :排水横枝管と通気立て管、ループ通気管の断面積 $\left[\mathrm{m}^{2}\right]$ \\
\hline$A_{B}$ & :排水横主管の断面積 $\left[\mathrm{m}^{2}\right]$ \\
\hline Qai & : 当該排水方式の各部での通気流量 [L/s] \\
\hline$Q a$ & :伸頂通気管の通気流量 [L/s] \\
\hline$\lambda$ & :摩擦損失係数 \\
\hline $\operatorname{Pmax}(k)$ & :各階圧力変動の最大值 $[\mathrm{Pa}]$ \\
\hline $\operatorname{Pmin}_{(k)}$ & :各階圧力変動の最小值 $[\mathrm{Pa}]$ \\
\hline Psmax & :システム最大圧力 $[\mathrm{Pa}]$ \\
\hline Psmin & : システム最小圧力 $[\mathrm{Pa}]$ \\
\hline $\operatorname{Pave}_{(k)}$ & : 各階平均圧力 $[\mathrm{Pa}]$ \\
\hline Pave (max) & :各階平均圧力の最大值 $[\mathrm{Pa}]$ \\
\hline Pave (min) & :各階平均圧力の最小值 $[\mathrm{Pa}]$ \\
\hline$\sigma_{1(k)}, \sigma_{2(k)}$ & : 各階最大·最小圧力の最大值・最小值の標準偏差 $[\mathrm{Pa}]$ \\
\hline$N_{1(k)}, N_{2(k)}$ & :各階最大·最小圧力の最大值·最小值の定数 \\
\hline$Q_{W}$ & :合計排水流量 [L/s] \\
\hline QSC & :排水能力 $[\mathrm{L} / \mathrm{s}]$ \\
\hline
\end{tabular}




\section{Masayuki OTSUKA ${ }^{* 1}$, Ryota SUGIMOTO ${ }^{* 2}$, Shin KOUNO *3 and Naofumi KOBAYASHI*4}

\footnotetext{
${ }^{* 1}$ Prof., Dept. of Architecture and Environmental Design, College of Architecture and Environmental Design, Kanto Gakuin Univ., Dr.Eng. *2 NIHON SEKKEI, INC. MEng. (Former Graduate School of Engineering, Kanto Gakuin Univ.)

${ }^{* 3}$ Takasago Thermal Engineering Co., Ltd., M.Eng. (Former Graduate School of Engineering, Kanto Gakuin Univ.)

${ }^{*}$ Hitachi Plant Services Co., Ltd., M.Eng. (Former Graduate School of Engineering, Kanto Gakuin Univ.)
}

In Japan at present, SHASE-S206 Plumbing Code regulates the drainage performance (permissible flow rate) of loop vent systems, but the prescribed value is not supported by systematic experimentation, and the theoretical grounds for it are yet to be clarified. Therefore, the study was conducted with the aim of clarifying the following three points: identifying the variation of internal pipe pressure and air flow rate characteristics when systematically applying drainage loads to a loop vent drainage system for high-rise buildings by the testing method specified by SHASE-S218; identifying the drainage performance of the system on the basis of the test results; and correlating said drainage performance with the permissible design flow rate specified by SHASE-S206 so as to propose new design data. Finally, to provide a theoretical basis, the analysis model for drainage/vent pipelines, which was previously proposed by the author and his fellow researchers, was expanded to propose a prediction method for identifying the drainage performance of loop vent drainage systems, and the practicality of the model was discussed. Consequently, the following points were clarified.

(1) In the simulation tower, the loop vent pipe connecting the horizontal fixture drain branch to the vent stack was installed in different locations; on one floor, two floors or all floors, to identify variations in the distribution of internal pipe pressure, and the maximum and minimum system values, which were obtained from the distribution of internal pipe pressure corresponding to each installation location in the single stack system (the standard system), were used as indices to quantitatively measure the relaxation rate, etc., of each value.

(2) In relation to (1), the flow rate of air sucked from the stack vent pipe was actually measured and it was pointed out that the measured flow rate was greater than the required flow rate calculated by the constant flow method specified by SHASE-S206, when the same drainage load flow rate was applied, and the difference between the flow rates was quantitatively obtained.

(3) The quantitative values of drainage performance of the respective vent systems were successfully obtained by testing the systems in accordance with SHASE-S218. The results indicated that the flow rates were below the SHASES206 permissible flow rate for loop vent systems when the house drain had elbows spaced at $1 \mathrm{~m}$ or $3 \mathrm{~m}$ intervals, i.e., not straight. However, it was indicated that the SHASE-S206 permissible flow rate could be reached more or less depending on the way of drawing the vent stack from the drainage stack and the degree of expansion of the diameter of the house drain.

(4) The pipe network analysis model proposed in the previous report was expanded and applied to the clarification of drainage performance of the loop vent system. Subsequently, it was indicated that when the house drain had elbows, the difference between the estimated value and the actual measured value of the maximum system value (positive pressure), a drainage performance index, was significant, but said difference was small when the house drain was straight. Therefore, the pipe network analysis model was deemed applicable. The analysis model was practically effective in the pipe configuration provided for this study, but for further study, a thorough consideration should be given to the airflow resistance in parts that constitute the model and for the optimization of suction power, while accuracy needs to be improved. 